\title{
Occurrence of Rhexocercosporidium carotae on cold stored carrot roots in the Netherlands
}

\author{
Pieter Kastelein · Eveline S. C. Stilma • \\ Janneke Elderson · Jürgen Köhl
}

Received: 10 March 2006/ Accepted: 18 December 2006/Published online: 24 January 2007 (C) KNPV 2007

\begin{abstract}
Winter carrot for the fresh market is an important cash crop for many organic arable farms in the Netherlands. In recent years carrot roots from cold stores have been affected by superficial dark brown to black spots. To gain insight into the pathogens causing the blemish and the effect of agronomic practices on their occurrence, surveys were carried out among crops harvested in 2001 and 2002. In addition carrots harvested in 2003 were screened for root spotting pathogens. Rhexocercosporidium carotae (syn. Acrothecium carotae and Pseudocercosporidium carotae) was the dominant pathogen in blackish spots on carrots harvested in 2001. On carrots harvested in 2002 and 2003 Alternaria radicina was detected more frequently. Multiple regression analysis indicated that a higher occurrence of the blemish may be linked with harvest conditions and presence of umbelliferous plants. The effect of the temperature on conidial germination, mycelial growth and pathogenicity of $R$. carotae was studied. The estimated optimum and maximum temperature for growth of $R$. carotae was 19 and $29^{\circ} \mathrm{C}$, respectively. Inoculation experiments demonstrated that wounds are good invasion
\end{abstract}

P. Kastelein $(\bowtie) \cdot$ E. S. C. Stilma · J. Elderson ·

J. Köhl

Plant Research International BV, P.O. Box 16, 6700

AA Wageningen, The Netherlands

e-mail: pieter.kastelein@wur.nl routes. Infection occurred at 3,10 and $20^{\circ} \mathrm{C}$, but not at $30^{\circ} \mathrm{C}$. Penetration into wounds was greatest at $20^{\circ} \mathrm{C}$.

Keywords Acrothecium carotae - Alternaria radicina - Organic farming - Root spotting . Storage disease

\section{Introduction}

For many organic arable farms carrot for the fresh market is an important cash crop. When mature carrot roots are harvested before winter and held in refrigerated storerooms for several months, returns are more profitable. However, in the last few years, superficial dark brown to black spots have developed during storage of the roots (Meier, 1998). When 5\% or more of the roots are affected, the whole consignment is rejected for the fresh market. In organic farming application of cultivation measures interfering with disease cycles are needed to prevent the blemish. To develop such preventive measures current knowledge of the pathogen(s) causing the spots and the effect of agronomic practices on their occurrence is required.

Several fungi may cause blackish lesions on carrots during storage (Snowdon, 1991). Of these Altenaria radicina, Chalaropsis thielavioides, Mycocentrospora acerina, and Thielaviopsis basi- 
cola are considered of importance for carrot growing in the Netherlands. Infections by Rhexocercosporidium carotae are sporadically found (Meier, 1998). The last pathogen was first described by Årsvoll (1965) as Acrothecium carotae. Subsequently, the fungus was successively classified in the genera Pseudocercosporidium (De Hoog \& Van Oorschot, 1985) and Rhexocercosporidium (Braun, 1994). The occurrence of $R$. carotae in rots on stored carrots has also been reported in Norway (Årsvoll, 1965), Denmark (Hobolth, 1983), Sweden ( Ewaldz, 1997; Jönsson, 2004; Pettersson, 1992) and Canada (Shoemaker, Hambleton, Lacroix, Tesolin, \& Coulombe, 2002).

To gain an insight into the blemish on organically-grown carrots, blackish spots on cold-stored roots were screened for fungi known to cause root spotting, and information on cropping patterns, crop husbandry and harvesting conditions was analysed for relationships with disease occurrence. This paper reports the widespread occurrence of $R$. carotae on spotted carrots harvested in 2001 and its subsequent diminution in the crops of the 2002 and 2003 growing seasons. For a better understanding of the pathogenicity of $R$. carotae, the effect of temperature on conidial germination, mycelial growth and invasiveness was studied. The temperature range in which the fungus grew and infected carrot roots is described.

\section{Materials and methods}

\section{Carrot cultivation and sampling}

During the 2001, 2002 and 2003 growing seasons, a total of 60 crops of intermediate carrot varieties from 26 different organic farms were sampled (Table 1). Five farms participated during two seasons, and five other farms all three seasons. The farms were located on clay soils in the southwest, the centre and the north of the Netherlands. All crops were grown to yield roots of 50-250 g for long-term storage. The mean acreage of the crops was 2 ha. The smallest crop covered .5 ha, whereas the largest crop had an area of 6 ha. The crops were sown in $5 \mathrm{~cm}$ strips on ridges between the beginning of May and mid-June; $82 \%$ of the crops were sown in May. The mean seed density
Table 1 Number of carrot crops of the 2001, 2002 and 2003 growing seasons which were surveyed and numbers of organic farms which participated in the study

\begin{tabular}{lllll}
\hline & \multicolumn{3}{l}{ Growing season } & \multirow{2}{*}{ Total } \\
\cline { 2 - 4 } & 2001 & 2002 & 2003 & \\
\hline Number of carrot crops & 19 & 23 & 18 & 60 \\
Number of participating farms & 15 & 14 & 12 & $26^{\mathrm{a}}$ \\
\hline
\end{tabular}

${ }^{a}$ The total number of participating farms differs from the result of the addition of the number of farms participating in each of the three seasons, because several of these farms participated during two or three seasons

was 2.0 million seeds $\mathrm{ha}^{-1}$. Minimum and maximum seed densities were 1.4 and 2.2 million seeds $\mathrm{ha}^{-1}$, respectively. In all crops the distance between ridges was $75 \mathrm{~cm}$.

The weather during the 2001 and 2002 growing seasons was warmer and wetter than normal (Table 2). Of these two seasons 2001 was the wettest. The 2003 growing season was also warm, but relatively dry. By the end of the 2001 growing season the foliage of $90 \%$ of the crops was severely affected by leaf blight (Alternaria dauci). In $2002,39 \%$ of the crops were severely affected by this disease, whereas in 2003 it caused hardly any damage. Powdery mildew was the most important foliar disease of the 2003 growing season, with $24 \%$ of the crops severely affected.

The crops were harvested between the end of September and mid-November; $84 \%$ of the crops were harvested in October. The time between sowing and harvest averaged 138 days; the shortest and longest growing times were 115 and 168 days, respectively. Harvesting was done with 'top-lift'-type carrot harvesters equipped with topping bars and an elevator system that enables direct filling of storage boxes in the field. The topped roots were transported to a cold-storage building on the harvest day and stored unwashed. On the harvest day of each crop the soil and the carrot roots were sampled. After the harvester had passed by, $250 \mathrm{ml}$ topsoil of three arbitrarily chosen carrot ridges was collected to determine the water content of the soil. From at least ten arbitrarily chosen storage boxes 20-30 roots were collected until two 151 crates were filled. Dependent on the size of the roots, 200-400 roots were collected from each crop. A sub-sample of 100 roots was used to assess the pre-storage sanitary 
Table 2 Weather conditions during the 2001, 2002 and 2003 growing seasons

\begin{tabular}{|c|c|c|c|c|c|c|c|c|c|c|c|c|}
\hline \multirow[t]{2}{*}{ Month } & \multicolumn{4}{|c|}{ Temperature $^{\mathrm{a}}$} & \multicolumn{4}{|c|}{ Global radiation $^{\mathrm{b}}$} & \multicolumn{4}{|c|}{ Precipitation $^{c}$} \\
\hline & 2001 & 2002 & 2003 & Normal $^{\mathrm{d}}$ & 2001 & 2002 & 2003 & Normal $^{\mathrm{d}}$ & 2001 & 2002 & 2003 & Normal $^{\mathrm{d}}$ \\
\hline April & 8.0 & 9.3 & 9.9 & 8.3 & 37.7 & 42.4 & 47.9 & 40.3 & 75 & 52 & 46 & 44 \\
\hline May & 13.7 & 13.2 & 13.2 & 12.7 & 64.0 & 51.5 & 54.2 & 54.7 & 34 & 41 & 85 & 57 \\
\hline June & 14.9 & 16.5 & 17.8 & 15.2 & 59.6 & 56.4 & 63.4 & 54.2 & 50 & 67 & 40 & 71 \\
\hline July & 18.5 & 17.4 & 18.8 & 17.4 & 58.9 & 52.3 & 60.0 & 54.7 & 71 & 88 & 57 & 70 \\
\hline August & 18.7 & 18.8 & 19.3 & 17.2 & 49.7 & 44.6 & 43.7 & 47.8 & 108 & 112 & 22 & 62 \\
\hline September & 13.6 & 15.1 & 13.9 & 14.2 & 27.0 & 34.0 & 38.0 & 30.8 & 177 & 39 & 53 & 75 \\
\hline October & 14.4 & 10.0 & 7.5 & 10.3 & 19.7 & 18.5 & 22.0 & 18.7 & 55 & 82 & 74 & 78 \\
\hline November & 7.5 & 8.0 & 8.0 & 6.2 & 8.7 & 8.9 & 9.2 & 8.7 & 90 & 87 & 49 & 82 \\
\hline Season & 13.7 & 13.5 & 13.6 & 12.7 & 325.4 & 308.5 & 338.4 & 309.9 & 660 & 568 & 426 & 539 \\
\hline
\end{tabular}

${ }^{a}$ Country means of the monthly and seasonal mean aerial temperatures in ${ }^{\circ} \mathrm{C}$. The country means are based on the measurements of the five main weather stations of the Royal Netherlands Meteorological Institute

$\mathrm{b}$ Country means of the monthly and seasonal sums of the global radiation in $\mathrm{kJ} \mathrm{cm}^{-2}$

c Country means of the monthly and seasonal sums of the precipitation in $1 \mathrm{~m}^{-2}$

d Long-term mean over the period 1971-2000

condition. The other roots were crated unwashed and stored in a cold room under conditions similar to those during commercial cold-storage. The samples of the 2001 and 2002 crops were stored for 4-5 months, whereas those of 2003 were stored for 3 months. After storage the post-harvest sanitary condition of the samples was assessed.

Assessment of the sanitary condition of root samples

To assess the sanitary condition of the samples, the roots were sprayed clean with tap water and allowed to dry. Then the roots were visually inspected for pests and diseases, which were identified by the appearance of lesions or damage. For each sample the number of roots affected by the various blemishes was recorded to calculate incidences. Amounts of root surface affected by the pests or diseases (severities) were not assessed. The decimal notation of the fraction of roots affected by blackish spots was used for data analysis.

\section{Screening for root spotting pathogens}

Only carrot roots affected by superficial dark brown to black spots were screened for presence of root spotting pathogens. From each sample all spots up to a maximum of 25 arbitrarily chosen spots were processed. From the roots sampled in 2001, 2002 and 2003, respectively, a total of 224,
106 and 263 lesions were examined. For each lesion size, shape and colour were recorded. Then the lesion with surrounding tissue was excised from the carrot root, placed on water-soaked filter paper in a Petri dish and incubated for 2 weeks at $15^{\circ} \mathrm{C}$ under NUV-illumination (Philips 'TL'D 18W/08) with a daily photoperiod of $12 \mathrm{~h}$. Lesions were inspected with a stereomicroscope for presence of conidia or chlamydospores of A. dauci, A. radicina, C. thielavioides, M. acerina, $T$. basicola and $R$. carotae, which are known to cause blackish spots (Snowdon, 1991). Fungi were identified by spore morphology (Årsvoll, 1965; Ellis, 1971). The method used to screen for root spotting pathogens does not allow for the detection of species with mycelia sterilia (e.g. Rhizoctonia solani).

For each sample the number of lesions infected by the various pathogens was recorded to calculate incidences. The decimal notation of the fraction of lesions infected by $R$. carotae was used for data analysis.

\section{Data collection}

Data on the crops harvested in 2001 and 2002 on farmland, cropping patterns, crop health, crop husbandry and harvesting conditions were gathered by means of field observations, crop analysis and questionnaires. Two weeks before the planned harvest date the crops were surveyed 
for symptoms of foliar diseases. The adjoining plots were examined for presence of umbelliferous crops and field margins were searched for umbelliferous plants. The 100-root sub-samples used for assessment of pre-storage sanitary conditions were also used for assessing dirt tare, topping efficiency, harvest damage (abrasions and other injuries) and plant analysis. The weight loss after washing was used to assess dirt tare. To assess topping efficiency the roots were grouped in four classes $(0=$ roots without remainders of petiole bases on the crown, $1=$ length of the remainders of the petiole bases $0-1 \mathrm{~cm}, 2=$ length of the remainders of the petiole bases $1-2 \mathrm{~cm}$, $3=$ remainders of petiole bases longer than $2 \mathrm{~cm}$ or one or more dead leaves attached to the crown). Then the roots in each class were counted and an index for topping efficiency was calculated using the formula:

Index $=100 \times\left(0 \times N_{0}+.33 \times N_{1}+.67 \times N_{2}+N_{3}\right) / N_{\text {total }}$

in which $N_{0}, N_{1}, N_{2}$ and $N_{3}$ is the number of carrots grouped in the classes $0,1,2$ and 3, respectively and $N_{\text {total }}$ is the total number of carrots in the sample. An index for topping efficiency of 0 indicates that the crowns of all roots were without remainders of petiole bases or leaves; 100 indicates that all roots had long remainders of petiole bases or dead leaves attached to the crown, i.e. removal of the foliage was unsatisfactory. The same formula was also used to calculate an index for mechanical damage caused during harvest. For assessing crop damage, the roots were grouped in the classes 0 (no visible damage), 1 (1-10\% of the periderm surface showing abrasions and wounds), 2 (11-25\% of the periderm surface showing abrasions and wounds) and 3 ( $>25 \%$ of the periderm surface showing abrasions and incisions). An index for mechanical damage of 0 indicates that none of the roots showed visible damage; whereas an index of 100 indicates that all roots were severally damaged (class 3 ). From carrots without blemishes, a random sample of 25 roots was sorted to determine dry matter content and contents of calcium $(\mathrm{Ca})$, magnesium $(\mathrm{Mg})$, potassium $(\mathrm{K})$ and sodium $(\mathrm{Na})$. The carrots were shredded and a fraction of the chips was weighed and dried at $105^{\circ} \mathrm{C}$ to determine the dry matter content (Houba, Van der Lee, \& Novozamsky, 1997). The bulk of chips was dried at $70^{\circ} \mathrm{C}$ and pulverized in a laboratory mill (Peppink Engineering Works, Amsterdam, The Netherlands) with a $1 \mathrm{~mm}$ mash sieve. The resulting powder was digested with $\mathrm{H}_{2} \mathrm{SO}_{4}$-salicylic acid- $\mathrm{H}_{2} \mathrm{O}_{2}$ and selenium (Temminghoff, Houba, Van Vark, \& Gaikhorst, 2000). The amounts of $\mathrm{Ca}, \mathrm{K}$ and $\mathrm{Na}$ in the digest were determined by flame atomic emission spectrometry, whereas the amount of $\mathrm{Mg}$ was determined by flame atomic absorption spectrometry. To assess soil wetness during harvest of the carrot crops the water content of the soil samples, obtained from carrot ridges on the day of harvest, was determined (Houba et al., 1997).

Questionnaires were used to obtain information on acreage, soil conditions (e.g. soil type, \% particles $<16 \mu \mathrm{m}, \mathrm{pH}, \%$ organic matter and nutrient levels) and cropping history of the plot (e.g. carrot-cropping frequency, crops and green manure crops grown in the ten preceding seasons and occurrence of blackish spots in previous carrot crops), primary and secondary tillage practices (e.g. management of crop residues, seed bed preparation and building of ridges), carrot variety, seed quality (e.g. seed size, hot water treatment), sowing (e.g. sowing time, drill width, seeding rate), time and uniformity of emergence, crop husbandry (e.g. weed and pest management, manuring and irrigation), harvest (e.g. harvesting equipment, harvesting time, weather conditions, wetness of the soil and the foliage) and the bordering plots (crops grown during current and preceding season, management of crop residues).

\section{Isolation and cultivation of $R$. carotae}

Isolations were made on Potato Carrot Agar (PCA; $20 \mathrm{~g} \mathrm{l}^{-1}$ potatoes, $20 \mathrm{~g} \mathrm{l}^{-1}$ carrots and $15 \mathrm{~g} \mathrm{l}^{-1}$ agar (Oxoid, nr. 3)) amended with $25 \mathrm{mg} \mathrm{l}^{-1}$ tetracycline. Peeled potatoes and scraped carrots were shredded and stored in $20 \mathrm{~g}$ portions at $-20^{\circ} \mathrm{C}$. To prepare the medium the potato and carrot shreds were soaked in water for $2 \mathrm{~h}$, cooked for $5 \mathrm{~min}$ and filtered through cheesecloth. The filtrate was adjusted to 11 and the agar was added. PCA was autoclaved for $15 \mathrm{~min}$ at $120^{\circ} \mathrm{C}$. 
Monoconidial isolate 840 of $R$. carotae was obtained from a black lesion on cold stored carrots of a 2001 crop grown in Flevoland (the Netherlands). The isolate was stored on PCA-slants at $3^{\circ} \mathrm{C}$. Mycelial inoculum was produced on Carrot Juice Agar (CJA). CJA contained $200 \mathrm{ml} \mathrm{l}^{-1}$ Akwarius carrot juice (Natuproducts BV, Harderwijk, The Netherlands) and $20 \mathrm{~g} \mathrm{l}^{-1}$ agar. CJA was autoclaved the same way as PCA. Cultures were incubated in the dark for 4 weeks at $18^{\circ} \mathrm{C}$. Agar discs (5 mm diam) with mycelium from the edge of the colonies was used as mycelial inoculum. Conidial inoculum was produced on carrot leaf extract enriched CJA. Fresh carrot leaves were crushed using a Pollähne leaf press (Meku, Wennigsen, Germany); $80 \mathrm{~g}$ pressed leaves were then mixed with $400 \mathrm{ml}$ water in a blender (Waring, New Hartford, Conn., USA). The fibre was separated from the leaf mousse by pressing the fluid through a colander. The leaf extract was stored in $100 \mathrm{ml}$ portions at $-20^{\circ} \mathrm{C}$. Enriched CJA contained $200 \mathrm{ml} \mathrm{l}^{-1}$ Akwarius carrot juice, $400 \mathrm{ml} \mathrm{l}^{-1}$ leaf extract and $20 \mathrm{~g} \mathrm{l}^{-1}$ agar. The medium was autoclaved the same way as PCA. Cultures were incubated at $18^{\circ} \mathrm{C}$, first for 3 weeks in the dark and thereafter for 7-10 days under NUV-illumination with a daily photoperiod of $12 \mathrm{~h}$. Conidial suspensions were obtained by flooding the cultures with sterile tap water, releasing the conidia from the mycelium by streaking the cultures with a glass Drigalski spatula, and straining the fluid through sterile nylon gauze with a mesh of $200 \mu \mathrm{m}$. Densities of conidial suspensions were determined by means of a haemocytometer and adjusted with sterile tap water. Conidial suspensions were kept on ice and used within $4 \mathrm{~h}$.

Effect of temperature on conidial germination in vitro

Conidial germination over time at different temperatures was determined on Petri dishes $(50 \mathrm{~mm}$ diam) containing $6 \mathrm{ml}$ Malt extract Agar (MA). MA contained $1 \mathrm{~g} \mathrm{l}^{-1}$ malt extract (Oxoid) and $15 \mathrm{~g} \mathrm{l}^{-1}$ agar. The day before use, the required Petri dishes with MA were placed in incubators at $0,5,10,15,20,25$ and $30^{\circ} \mathrm{C}$. The temperature of $0^{\circ} \mathrm{C}$ was obtained by placing the Petri dishes in a box surrounded on all sides with melting ice. On the day of inoculation two conidial suspensions were prepared at a $12 \mathrm{~h}$ interval. The suspensions containing $5 \times 10^{5}$ conidia $\mathrm{ml}^{-1}$ were atomized onto the medium to obtain approximately 75 conidia $\mathrm{mm}^{-2}$ on the agar surface. Immediately after inoculation the Petri dishes were replaced in the appropriate incubator. The total incubation period of the conidia depended on the temperature. The incubation periods $\left(0^{\circ} \mathrm{C}: 72 \mathrm{~h} ; 5^{\circ} \mathrm{C}: 24 \mathrm{~h}\right.$; $10^{\circ} \mathrm{C}: 20 \mathrm{~h} ; 15^{\circ} \mathrm{C}: 10 \mathrm{~h} ; 20^{\circ} \mathrm{C}: 10 \mathrm{~h} ; 25^{\circ} \mathrm{C}: 20 \mathrm{~h}$; $30^{\circ} \mathrm{C}: 16 \mathrm{~h}$ ) were divided into $2 \mathrm{~h}$ (incubation for $10 \mathrm{~h}$ ), $4 \mathrm{~h}$ (incubation for 16-24 h) or $24 \mathrm{~h}$ (incubation for $72 \mathrm{~h}$ ) intervals and after each time interval the fungal growth in two Petri dishes was stopped by placing the plates over filter paper saturated with household ammonia water $(4.8 \%$ $\left.\mathrm{NH}_{4} \mathrm{OH}\right)$. The use of two conidial suspensions made it possible to avoid late night sampling during the course of the experiment.

Conidial germination was quantified by microscopic examination of 100 arbitrary, free-lying conidia per plate. A conidium was assessed as germinated whenever the length of the germ tube was at least one third of the length of the conidium. For each incubation period/incubation temperature combination, the average was taken of the $\%$ germinated conidia found in the duplicate plates to describe conidial germination over time. The experiment was carried out twice.

Effect of temperature on mycelial growth in vitro

Mycelial growth rates of $R$. carotae were determined at $0,5,10,15,20,25$ and $30^{\circ} \mathrm{C}$. Mycelial inoculum was placed in the centre of Petri dishes (90 mm diam) containing $17 \mathrm{ml}$ half strength CJA. At each temperature level four plates were incubated in the dark for 28 days. Radial growth of colonies along two perpendicular lines was recorded at 7-day intervals. The weekly growth rates were measured and for each Petri dish the mean growth rate was used for data analysis. The experiment was carried out twice.

Inoculation of carrots

Unwashed mature carrot roots (cv. Nerac) were obtained from an organic farm in Flevoland and 
stored at $3^{\circ} \mathrm{C}$ for up to 6 months. Before use the carrots were subsequently sprayed clean with tap water, surface-sterilized for $2 \mathrm{~min}$ in $.5 \%$ sodium hypochlorite, rinsed three times in water and dried for $1 \mathrm{~h}$. Shortly before inoculation with $R$. carotae, carrots were wounded as described below at four spots at one side of the root. The wounded areas were 1-2 cm long and about $1 \mathrm{~cm}$ wide. After inoculation of the fresh wounds with $20 \mu$ l suspension containing $1 \times 10^{5}$ conidia $\mathrm{ml}^{-1}$, the carrots were incubated in moist chambers as specified below for 3 weeks. Wounds treated with sterile tap water were used as the non-inoculated control. At the end of the incubation period the inoculated patches of skin were examined for colonization and development of blackish spots. A crosscut was made through the lesions to measure the penetration depth.

In one experiment three types of wounding were applied. Wounding type 1 (no wounds), type 2 (abrasions) was wounding by a graze with medium-coarse sandpaper and type 3 (open wounds) was by superficially removing a piece of the periderm with a parer. The experiment was set up in a randomized complete block design. Each of the ten repetitions contained two inoculated carrots and one non-inoculated control carrot per wounding type. The carrots were incubated at $18^{\circ} \mathrm{C}$. For each repetition the decimal notation of the fraction of blackish spots and the mean of the depths of the eight lesions per wounding type was used for statistical analysis. The experiment was carried out once.

Another experiment assessed the effect of the temperature on the ability of $R$. carotae to infect open wounds. The temperatures were $0,3,10,20$, or $30^{\circ} \mathrm{C}$. At each temperature 20 inoculated carrots and ten non-inoculated control carrots were incubated. The decimal notation of the fraction of colonized patches and the mean of the depths of the four lesions per carrot was used for statistical analysis. The experiment was carried out once.

\section{Statistical analysis}

To interrelate disease occurrence with the information collected on the crops grown in 2001 and in 2002 a method was used similar to that described by Den Belder, Elderson, Van den Brink, and Schelling (2002). For each season a separate multiple linear regression analysis was performed with the RSEARCH procedure in the Genstat 6.1 programme (Payne et al., 2002). The information analysed included in total 14 categorical variables and 21 quantitative variables, which were grouped into six categories (Table 3 ). Using arcsin-transformed values of the dependent variables 'fraction of roots affected by blackish spots' or 'fraction of spots with $R$. carotae' the analysis was performed in two steps. In step 1 the independent terms were presented in four groups: (1) the quantitative variables of the categories 'soil conditions', 'crop rotation', 'surrounding area' and 'crop husbandry'; (2) the quantitative variables of the categories 'harvest conditions', and 'composition of the carrots'; (3) categorical variables of the categories 'soil conditions' and 'crop husbandry'; (4) categorical variables of the categories 'crop rotation' and 'surrounding area'. For each group the terms best explaining the dependent variables were selected based on Mallow's $C_{p}$-values close to the number of independent terms $(p)$ and the largest adjusted $R^{2}$. In step 2 of the analysis the terms selected in step 1 were combined and presented for a second round of selection and elimination of independent terms to provide models with numbers of $p$ as small as possible.

To analyse the effect of the temperature on mycelial growth of $R$. carotae a Logan curve (Logan, Wollkind, Hoyt, \& Tanigoshi, 1976) was fitted through the mycelial growth rates at the different temperatures. Logan curves are described by:

$$
\left\{\begin{array}{l}
Y(T)=\psi \times[\exp (\rho \times(T-\mathrm{Tb}))-\exp (\rho \times(\mathrm{TM} \\
-\mathrm{Tb}))-(\mathrm{TM}-T) / \Delta T] \text { for } T \leq \mathrm{TM} \\
Y(T)=0 \text { for } T \geq \mathrm{TM}
\end{array}\right.
$$

in which $Y$ is mycelial growth rate, $T$ is temperature, $\mathrm{Tb}$ is the lower threshold temperature and TM is the upper lethal temperature. Values of $\psi$, $\rho, \mathrm{Tb}, \mathrm{TM}$ and $\Delta T$ were estimated by non-linear regression analysis. The equation of the Logan curve and the estimates of the parameters were used to calculate the optimum temperature (the 
Table 3 Numbers of independent variables per category of information on the carrot crops harvested in 2001 and 2002

\begin{tabular}{lll}
\hline Category & $\begin{array}{l}\text { Quantitative } \\
\text { variables }\end{array}$ & $\begin{array}{l}\text { Categorical } \\
\text { variables }\end{array}$ \\
\hline Soil conditions $^{\mathrm{a}}$ & 2 & 1 \\
Crop rotation $^{\mathrm{b}}$ & 5 & 4 \\
Surrounding area $^{\mathrm{c}}$ & 0 & 4 \\
Crop husbandry $^{\mathrm{d}}$ & 3 & 5 \\
Harvest conditions $^{\mathrm{e}}$ & 6 & 0 \\
Chemical composition & 5 & 0 \\
$\quad$ of carrot roots $^{\mathrm{f}}$ & &
\end{tabular}

${ }^{a}$ Quantitative variables: $\%$ particles $<16 \mu \mathrm{m}, \%$ organic matter; Categorical variable: soil type

b Quantitative variables: No. of gramineous crops in the three and five preceding seasons, No. of leguminous crops in the three and five preceding seasons, carrot-cropping frequency; Categorical variables: preceding crop, second last crop, green manure crop preceding carrot, green manure crop after second last crop

c Categorical variables: presence of umbelliferous plants in the field margins, presence of a carrot crop on a bordering plot, cultivation of carrots on a bordering plot during the preceding season, presence of trees or shrubs in the near environment

d Quantitative variables: crop length, cultivated area, seeding rate; Categorical variables: variety, optimal seedling emergence (yes or no); irrigation during emergence (yes or no), application of $\mathrm{N}$ and $\mathrm{K}$ during growing season (yes or no)

e Quantitative variables: aerial temperature, soil temperature, soil moisture, tare weight, index for topping efficiency, index for mechanical damages

${ }^{\mathrm{f}}$ Quantitative variables: dry matter content, Ca-, K-, Mgand Na-content

temperature with the highest $Y(T)$ value) for growth.

Analysis of variance (ANOVA) was used to analyse the data of the inoculation experiments. Least significant difference (LSD) tests $(\alpha=.05)$ were used for evaluating the significance of differences between pairs of treatment means.

\section{Results}

Occurrence of blackish spots

At harvest time of 2001 no blackish spots were found on carrot roots. However, in 2002 and 2003 the blemish was already found at harvest in 26 and $11 \%$ of the samples. In these samples .4-7\%
Table 4 Occurrence of blackish spots on cold stored carrot roots collected in 2001, 2002 and 2003

\begin{tabular}{lccc}
\hline Growing season & Prevalence $^{\mathrm{a}}$ & \multicolumn{2}{l}{ Incidence $^{\mathrm{b}}$} \\
\cline { 3 - 4 } & & Mean & Range \\
\hline 2001 & 100 & 9 & $2-21$ \\
2002 & 83 & 2 & $0-10$ \\
2003 & 100 & 31 & $7-66$
\end{tabular}

${ }^{a}$ Percentage samples in which blackish spots were found

b Mean and range of the percentages of affected roots in the 19, 23 and 18 samples collected in 2001, 2002 and 2003, respectively

of the roots showed blackish spots. At the end of storage all samples collected in 2001 and 2003 contained carrots showing blackish spots (Table 4). The blemish affected 2-21\% and $7-66 \%$ of the roots in the samples of 2001 and 2003 , respectively. In $83 \%$ of the samples of the 2002 growing season only $1-10 \%$ of the roots showed blackish spots, whereas the other samples did not contain spotted roots. The mean incidence of the blemish was 9,2 and $31 \%$ for the samples of 2001, 2002 and 2003, respectively. The diversity in appearance of the lesions, even within samples, was considerable. Some spots were dark brown or black in colour, others had a brown centre with a black edge. In some cases the centre of the spot was sunken. Most lesions were irregularly shaped, although also round, oval and bar like spots occurred. Lesions were superficial, up to $2 \mathrm{~mm}$ deep. In 2001 and 2002 the majority of the lesions were black coloured, whereas in 2003 dark brown, slightly sunken lesions with a black edge were predominant.

\section{Occurrence of root spotting pathogens}

In the scarce blackish spots that were already present at harvest, either $A$. dauci, A. radicina, or $C$. thielavioides was detected. From blackish spots which had developed during cold storage of the carrots harvested in 2001, 2002 and 2003, respectively, 66, 53 and $32 \%$ revealed spores of fungi known to cause root spotting. In $50 \%$ of the lesions on roots harvested in $2001 R$. carotae was detected (Table 5). This pathogen was found to occur in samples from all three regions surveyed. The prevalence of $R$. carotae for the 2001 growing 
Table 5 Occurrence of pathogens in blackish spots on cold stored carrot roots and their distribution among the samples collected in 2001, 2002 and 2003

\begin{tabular}{|c|c|c|c|c|c|c|}
\hline \multirow[t]{2}{*}{$\begin{array}{l}\text { Root spotting } \\
\text { pathogen }^{\text {a }}\end{array}$} & \multicolumn{3}{|c|}{$\begin{array}{l}\text { \% lesions with } \\
\text { pathogen }\end{array}$} & \multicolumn{3}{|c|}{$\begin{array}{l}\% \text { samples with } \\
\text { pathogen }^{b}\end{array}$} \\
\hline & 2001 & 2002 & 2003 & 2001 & 2002 & 2003 \\
\hline $\begin{array}{l}\text { Rhexocercosporidium } \\
\text { carotae }\end{array}$ & 50 & 11 & 1 & 74 & 22 & 6 \\
\hline Alternaria radicina & 8 & 23 & 25 & 26 & 35 & 61 \\
\hline Alternaria dauci & 6 & 14 & 2 & 47 & 13 & 17 \\
\hline $\begin{array}{l}\text { Chalaropsis } \\
\text { thielavioides }\end{array}$ & 1 & 5 & 0 & 5 & 4 & 0 \\
\hline $\begin{array}{l}\text { Mycocentrospora } \\
\text { acerina }\end{array}$ & 1 & 0 & 4 & 11 & 0 & 22 \\
\hline $\begin{array}{l}\text { No sporulation of } \\
\text { root spotting } \\
\text { pathogens }\end{array}$ & 34 & 47 & 68 & 16 & 39 & 28 \\
\hline $\begin{array}{l}\text { Number of lesions or } \\
\text { samples examined }\end{array}$ & 224 & 106 & 263 & 19 & 23 & 18 \\
\hline \multicolumn{7}{|c|}{$\begin{array}{l}\text { a The identity of the pathogens was established by spore } \\
\text { morphology }\end{array}$} \\
\hline \multicolumn{7}{|c|}{$\begin{array}{l}\mathrm{b} \text { For each year the sum of the percentages of samples } \\
\text { with the various root spotting pathogens differs from } 100 \\
\text { because in most samples more than one pathogen was } \\
\text { detected }\end{array}$} \\
\hline
\end{tabular}

season was $74 \%$. On carrots harvested in the following seasons $R$. carotae was, with a prevalence of 22 and $6 \%$ for 2002 and 2003, respectively, of lesser importance. In the samples of these seasons $A$. radicina was detected most frequently. Furthermore, A. dauci, C. thielavioides and $M$. acerina were detected in blackish spots. In most samples more than one root spotting pathogen occurred. Mostly one pathogen was detected in the lesions, however, in ten out of the 593 lesions screened $R$. carotae and another root spotting pathogen (A. dauci: $5 \times$; A. radicina: $3 \times$; $C$. thielavioides: $2 \times$ ) was present. Other pathogen combinations were not found. No relationships were found between lesion type (size, shape or colour) and root spotting pathogen detected in the lesions.

Factors affecting the occurrence of blackish spots and $R$. carotae

A high index for mechanical damage (Table 6, crops harvested in 2001, $P=.006$ ) or a high temperature (Table 6, crops harvested in 2002, $P=.030)$ during harvest was associated with a high incidence of blackish spots. In the carrot samples of 2001 from plots where umbelliferous plants were present in the field margin, the incidences of the blemish were higher (Table 6, $P=.014)$ than in the samples from plots with margins in which umbelliferous plants were not found. The occurrence of $R$. carotae in blackish spots was linked with the presence of umbelliferous plants in the field margin and the calcium content of roots (Table 7, crops harvested in 2001, $P=.004$ and $P=.005$, respectively) or the cultivation of carrots on one of the bordering plots during the 2001 growing season and topping efficiency during harvest (Table 7, crops harvested in 2002, $P=.006$ and $P=.023$, respectively). A high calcium content of roots (2001) or a high index for topping efficiency, i.e. more roots

Table 6 Accumulated analysis of variance, the variable being the incidence of black spotted carrots after cold storage of root samples from 19 and 23 carrot crops harvested in 2001 and 2002, respectively

\begin{tabular}{|c|c|c|c|c|c|}
\hline Source of variation & d.f. & SS & $F$-value & $P>F$ & Coefficient \\
\hline \multicolumn{6}{|l|}{ Carrot crops harvested in 2001, adjusted $R^{2}=40.1 \%$} \\
\hline Index for mechanical damages caused during harvest ${ }^{\mathrm{a}}$ & 1 & .075 & 9.99 & .006 & .006 \\
\hline Presence of umbelliferous plants in the field margins ${ }^{b}$ & 1 & .057 & 7.62 & .014 & .155 \\
\hline Residual & 16 & .119 & & & \\
\hline Total & 18 & .224 & & & \\
\hline \multicolumn{6}{|l|}{ Carrot crops harvested in 2002, adjusted $R^{2}=16.8 \%$} \\
\hline Aerial temperature during harvest ${ }^{\mathrm{c}}$ & 1 & .033 & 5.46 & .030 & .013 \\
\hline Residual & 21 & .127 & & & \\
\hline Total & 22 & .160 & & & \\
\hline
\end{tabular}

\footnotetext{
a The index for mechanical damages caused during the harvest in 2001 ranged from 8.7 (few damaged roots) to 46.7

b Umbelliferous plants were found in the field margins of $16 \%$ of the crops grown in 2001

${ }^{c}$ For the crops harvested in 2002 the mean aerial temperature on the harvest day ranged from 6.1 to $15.6^{\circ} \mathrm{C}$
} 
Table 7 Accumulated analysis of variance, the variable being the incidence of $R$. carotae infected blackish spots on cold stored roots from 19 and 23 carrot crops harvested in 2001 and 2002, respectively

\begin{tabular}{|c|c|c|c|c|c|}
\hline Source of variation & d.f. & SS & $F$-value & $P>F$ & Coefficient \\
\hline \multicolumn{6}{|l|}{ Carrot crops harvested in 2001, adjusted $R^{2}=46.9 \%$} \\
\hline Presence of umbelliferous plants in the field margins ${ }^{\mathrm{a}}$ & 1 & .999 & 11.18 & .004 & .643 \\
\hline Calcium content of roots at harvest time ${ }^{\mathrm{b}}$ & 1 & .931 & 10.42 & .005 & -1.239 \\
\hline Residual & 16 & .119 & & & \\
\hline Total & 18 & .224 & & & \\
\hline \multicolumn{6}{|l|}{ Carrot crops harvested in 2002 , adjusted $R^{2}=28.6 \%$} \\
\hline Cultivation of carrots on a bordering plot during the preceding season ${ }^{c}$ & 1 & .013 & 9.32 & .006 & .071 \\
\hline Index for topping efficiency during harvest ${ }^{\mathrm{d}}$ & 1 & .008 & 6.11 & .023 & -.003 \\
\hline Residual & 20 & .028 & & & \\
\hline Total & 22 & .043 & & & \\
\hline
\end{tabular}

${ }^{a}$ Umbelliferous plants were found in the field margins of $16 \%$ of the crops grown in 2001

b The calcium content of the crops grown in 2001 ranged from 3.9 to $4.6 \mathrm{~g} \mathrm{~kg}^{-1}$ fresh carrots

c In 2002, 4\% of the crops bordered on a plot on which carrots were grown in 2001

${ }^{\mathrm{d}}$ For the crops harvested in 2002 the index for topping efficiency ranged from 7.0 (few roots with remainders of petiole bases attached to the crown) to 42.8

with long remainders of petiole bases (2002), was associated with a low incidence of $R$. carotae in the blackish lesions.

Effect of temperature on germination of $R$. carotae conidia

Germination of conidia was slowest at $0^{\circ} \mathrm{C}$ (Table 8). At this temperature the first germinated conidia were found $48 \mathrm{~h}$ after inoculation, whereas at higher incubation temperatures the first germ tubes appeared within $4 \mathrm{~h}$. After $72 \mathrm{~h}$

Table 8 The effect of temperature on the germination of $R$. carotae conidia

\begin{tabular}{|c|c|c|c|c|c|c|c|}
\hline & \multicolumn{7}{|c|}{ Temperature $\left({ }^{\circ} \mathrm{C}\right)$} \\
\hline & 0 & 5 & 10 & 15 & 20 & 25 & 30 \\
\hline Total incubation period (h) & 72 & 24 & 20 & 10 & 10 & 20 & 16 \\
\hline $\begin{array}{l}\text { Time }(\mathrm{h}) \text { of initial conidial } \\
\text { germination }^{\mathrm{a}}\end{array}$ & 48 & 4 & 4 & 2 & 4 & 4 & 4 \\
\hline $\begin{array}{l}\text { Maximum percentage of } \\
\text { germinated conidia at the } \\
\text { end of the total incubation } \\
\text { period }\end{array}$ & 60 & 94 & 99 & 100 & 100 & 63 & 35 \\
\hline $\begin{array}{l}\text { Time }(\mathrm{h}) \text { of maximum } \\
\text { conidial germination }^{\mathrm{b}}\end{array}$ & - & 20 & 16 & 10 & 10 & 16 & 8 \\
\hline \multicolumn{8}{|c|}{$\begin{array}{l}\text { a Time of initial conidial germination is the time of the } \\
\text { first sampling after inoculation in which germinated } \\
\text { conidia occurred }\end{array}$} \\
\hline \multicolumn{8}{|c|}{$\begin{array}{l}\mathrm{b} \text { Time of maximum conidial germination is the time of } \\
\text { the first sampling in which the maximum percentage of } \\
\text { germinated conidia was reached }\end{array}$} \\
\hline
\end{tabular}

incubation at $0^{\circ} \mathrm{C}$ an average of $60 \%$ conidia had germinated. At $5-20^{\circ} \mathrm{C}$ more than $90 \%$ conidia had germinated within $24 \mathrm{~h}$. At 25 and $30^{\circ} \mathrm{C}$ the increase in $\%$ germinated conidia had stopped before the end of the incubation period at average levels of 63 and $35 \%$, respectively.

Effect of temperature on mycelial growth of $R$. carotae

At temperatures between 0 and $20^{\circ} \mathrm{C}$ the mycelial growth rates ranged from $.6 \pm .6 \mathrm{~mm}$ per week at $0^{\circ} \mathrm{C}$ to $15.8 \pm .5 \mathrm{~mm}$ per week at $20^{\circ} \mathrm{C}$ (Fig. 1). At $25^{\circ} \mathrm{C}$ the growth rate was $5.1 \pm .4 \mathrm{~mm}$ per week and at $30^{\circ} \mathrm{C}$ the fungus did not grow at all. The Logan curve fitted through the observed growth rates, matched the data of temperatures above $5^{\circ} \mathrm{C}$ more accurately than those of $0^{\circ} \mathrm{C}$. At $0^{\circ} \mathrm{C}$ the actual growth rate was much lower than the estimated rate. On the basis of the Logan equation the optimum and maximum temperatures for growth of $R$. carotae were 19 and $29^{\circ} \mathrm{C}$, respectively.

\section{Pathogenicity of $R$. carotae}

In the inoculation experiment at $18^{\circ} \mathrm{C}$ with three types of wounding (no wounds, abrasions and open wounds) $R$. carotae developed dark brown lesions in all types of wounds. This discolouration did not develop in water controls. Periderm 


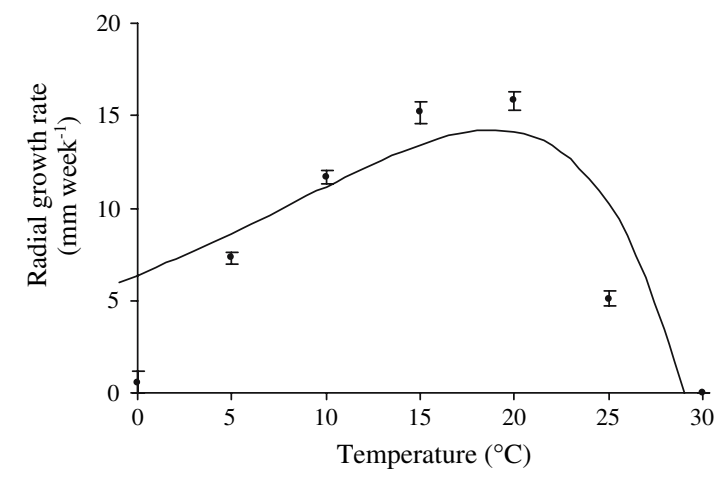

Fig. 1 Mycelial growth rates of $R$. carotae at different temperatures. The line represents the fitted Logan curve $Y(T)=107 \times[\exp (.096 \times(T-5))-\exp (.096 \times(29-5)-$ $(29-T) / 10)] ; R^{2}=90.6 \%$. Each point and error bar represents the mean and corresponding standard deviation of the eight growth rates measured at that temperature

without mechanical wounding was most resistant to the pathogen: only an average of $36 \%$ of the inoculated patches showed small lesions (Table 9). All open wounds and an average of $96 \%$ of the abrasions were penetrated by the fungus. In all cases lesion depths did not exceed $2 \mathrm{~mm}$. Depths of lesions in patches with abrasions did not differ from those in patches with open wounds.

The temperature had a marked effect on the ability of $R$. carotae to penetrate open wounds. At $0^{\circ} \mathrm{C}$ an average of $51 \%$ of the wounds were colonized by the pathogen. However, at $0^{\circ} \mathrm{C}$ the colonized tissues did not develop into brown

Table 9 Ability of $R$. carotae to infect different types of wounds. Percentage patches infected by the pathogen and lesion depths after incubation of inoculated patches of periderm during 3 weeks at $18^{\circ} \mathrm{C}$

\begin{tabular}{lll}
\hline $\begin{array}{l}\text { Wounding } \\
\text { type }^{\mathrm{A}}\end{array}$ & $\begin{array}{l}\text { Infected patches } \\
(\%)^{\mathrm{B}}\end{array}$ & $\begin{array}{l}\text { Penetration depth } \\
(\mathrm{mm})^{\mathrm{B}}\end{array}$ \\
\hline No wounds & $36 \pm 28 \mathrm{a}$ & $.05 \pm .06 \mathrm{a}$ \\
Abrasions & $96 \pm 12 \mathrm{~b}$ & $.81 \pm .35 \mathrm{~b}$ \\
Open wounds & $100 \pm 0 \mathrm{~b}$ & $.92 \pm .26 \mathrm{~b}$ \\
\hline
\end{tabular}

A No wounds: periderm without mechanical wounding; Abrasions: periderm wounded by a graze with sandpaper; Open wounds: periderm removed with a parer

в Values presented are the means and standard deviations for the percentage of infected patches and the mean lesion depth of eight patches on carrot roots with ten replicates. Values followed by different letters are significantly different (LSD-test; $\alpha=.05$ )
Table 10 Effect of temperature on the ability of $R$. carotae to infect patches of periderm wounded with a parer (open wounds)

\begin{tabular}{lll}
\hline $\begin{array}{l}\text { Temperature } \\
\left({ }^{\circ} \mathrm{C}\right)\end{array}$ & $\begin{array}{l}\text { Colonized patches } \\
(\%)^{\mathrm{A}}\end{array}$ & $\begin{array}{l}\text { Penetration depth } \\
(\mathrm{mm})^{\mathrm{A}}\end{array}$ \\
\hline 0 & $51 \pm 5 \mathrm{~b}$ & $.05 \pm .03 \mathrm{a}$ \\
3 & $90 \pm 17 \mathrm{c}$ & $.17 \pm .10 \mathrm{~b}$ \\
10 & $98 \pm 8 \mathrm{c}$ & $.62 \pm .19 \mathrm{c}$ \\
20 & $85 \pm 29 \mathrm{c}$ & $.80 \pm .38 \mathrm{~d}$ \\
30 & $0 \pm 0 \mathrm{a}$ & $.00 \pm .00 \mathrm{a}$ \\
\hline
\end{tabular}

Percentage patches colonized by the pathogen and lesion depths after incubation of inoculated wounds during 3 weeks at $0,3,10,20$ and $30^{\circ} \mathrm{C}$

A Values presented are the means and standard deviations for the $\%$ of colonized patches and the mean lesion depth of four patches per carrot root with 20 replicates. Values followed by different letters are significantly different (LSD-test; $\alpha=.05$ )

lesions (Table 10). After incubation at 3, 10 and $20^{\circ} \mathrm{C}$ brown lesions appeared in an average of 90 , 98 and $85 \%$ of the wounds, respectively. The colour of the lesions ranged from pale brown at $3^{\circ} \mathrm{C}$ to dark brown at $20^{\circ} \mathrm{C}$. At $30^{\circ} \mathrm{C}$ no signs of infection were found. The lesion depth was greatest at $20^{\circ} \mathrm{C}$.

\section{Discussion}

In the Netherlands $A$. radicina is considered to be the main cause of blackish spots in stored carrots. In addition $C$. thielavioides, $T$. basicola and $M$. acerina are increasingly detected (Meier, 1998). Except for T. basicola, these root spotting pathogens were found to occur in lesions on carrots collected during present surveys. Furthermore $A$. dauci and $R$. carotae were detected in lesions. So far, $R$. carotae was occasionally isolated by the Dutch Plant Protection Service in the years 1986-1988. Extent of disease occurrence and geographical distribution were poorly documented. Therefore the frequent occurrence of $R$. carotae in organic carrot roots grown in 2001 was unexpected.

Except for the reports of Arsvoll (1965) and Ewaldz (1997), most reports (Hobolth, 1983; Jönsson, 2004; Pettersson, 1992; Shoemaker et al., 2002) on loss of stored carrots due to $R$. carotae do not elaborate on the extent of disease occurrence. 
In surveys of stored carrots made during 19621965 in Norway the pathogen was found to be common in the county Rogaland but occurred sporadically in other parts of the country. During winter of 1963/1964 R. carotae rot affected about $20 \%$ of the storage stock of carrots grown in Rogaland (Årsvoll, 1965). In field experiments conducted in 1991-1992 in Sweden R. carotae affected on average $77.5 \%$ of the stored carrots from the two experiments of 1991, but was not found in 1992 (Ewaldz, 1997). Also during the present study incidences of $R$. carotae in stored carrots were substantial in one season and minor in the two subsequent seasons.

The fungus $R$. carotae has been described by Årsvoll (1965) and Shoemaker et al. (2002). By laboratory experiments Årsvoll (1965, 1971) obtained information on the ecophysiology and pathogenicity of the fungus. However, knowledge on the effect of agricultural practices and environmental factors on disease occurrence and disease severity is lacking. In a first effort to fill this hiatus, information on cropping patterns, crop husbandry and harvesting conditions was analysed for relationships with disease occurrence. The results of the multiple regression analysis point to a possible importance of issues associated with harvesting (mechanical damages, topping efficiency and aerial temperature), the calcium content of roots and the presence of umbelliferous plants in the field margin or carrot crops on a bordering plot during the preceding season. Although the number of carrot crops was relatively small in proportion to the number of independent variables, the following factors best explain the occurrence of the blemish or the presence of $R$. carotae in blackish spots: (1) Many pathogenic fungi enter plants through wounds, i.e. mechanical damages, formed during harvest (Agrios, 1997). (2) The topping efficiency represents the harvestability of the crop and is determined by the vigour of the foliage, the uniformity of the ridges and adjustments of the harvester. Healthy and strong foliage, for example, allows the gripper belts of top-lifting harvesters to go at a lower speed, thus reducing the chance of mechanical damage. (3) The temperature has an effect on processes involved in host defence (Bostock \& Stermer, 1989) as well as in fungal pathogenesis
(Årsvoll, 1971). (4) Calcium reduces the severity of several diseases because of its effect on the composition of cell walls and their resistance to penetration by pathogens (Moerschbacher \& Mendgen, 2000) and its role in early signal transduction in host-pathogen interactions (Boller \& Keen, 2000). (5) In many diseases of annual crops the inoculum survives in perennial weeds or alternate hosts, and every season it is carried from them to the annual crop and other plants. Some fungi affecting annual plants overwinter as mycelium, resting or other spores or as sclerotia in infected plant debris (Agrios, 1997; Krupinsky, Bailey, McMullen, Gossen, \& Turkington, 2002). The inconsistency in the results of the analysis for the crops harvested in 2001 and 2002 may be connected with the low number of crops involved. Because of this low number of observations it is possible that a single observation strongly influenced the outcome of the analyses. Furthermore, the inconsistency may be connected with the annual differences in the abundance of the various root spotting pathogens in general (occurrence of blackish spots) and of $R$. carotae in particular (presence of $R$. carotae in lesions). Therefore, further observational and experimental research is needed to verify the importance of above-mentioned contributing factors.

The use of mechanical harvesting equipment always incurs damage to carrot roots (Tucker, 1974). The inoculation experiment with different wounding types (Table 9) has demonstrated that $R$. carotae can effectively infect damaged areas of the skin of carrot roots. So, avoidance of mechanical damage during harvest is a possible way to prevent infections by this pathogen. Quite often foliar diseases (e.g. leaf blight) and the current logistics of carrot root harvesting make this impracticable. Since curing has been found to reduce losses in crops infested by $M$. acerina (Hoftun, 1993), pre-storage treatments to harden the periderm and heal wounds may also be useful to control $R$. carotae. But measures that prevent crops from becoming contaminated will be more effective. For this purpose inoculum sources of $R$. carotae need to be known. The relationships with umbelliferous plants and the cultivation of carrot crops during the preceding season indicate that infected umbelliferous plants or their remains 
may be a source of inoculum which is vectored by wind or otherwise to susceptible carrot crops. However, a small scale screening of umbelliferous plants in field margins of the crops surveyed in 2002 did not lead to the identification of hosts of $R$. carotae (data not presented). Furthermore, the use of the carrot disk soil assay described by Tabachnik, DeVay, Garber, and Wakeman (1979) to detect $T$. basicola in soil, did not yield positive results for $R$. carotae with soil samples taken during spring 2003 from four fields on which affected crops had been grown in 2002 (data not presented). A more systematic survey of the presence of the pathogen on wild and cultivated umbelliferous plants, as well as on crop remains or in soil is therefore needed to identify inoculum sources.

At harvest time blackish spots associated with $R$. carotae were not found, whereas such lesions were indeed present after cold storage, thus indicating the blemish had developed during storage. Furthermore, the occurrence of $R$. carotae in spots was linked with harvest damage. To explore at what temperatures contaminated wounds can develop into lesions, the effect of temperature on aspects of the pathogenicity of $R$. carotae, i.e. conidial germination, mycelial growth and the penetration of carrot roots was studied. The responses of the germination rate, growth rate and lesion depth to the different temperatures showed similar trends. The temperature growth curve for $R$. carotae isolate 840 (Fig. 1) resembles that described by Årsvoll (1965) for a Norwegian isolate. For the latter isolate a minimum temperature for growth was found under $-3^{\circ} \mathrm{C}$. Temperatures close to $18^{\circ} \mathrm{C}$ and a little higher than $25^{\circ} \mathrm{C}$ were the estimates of the optimum and maximum temperature for growth, respectively. By fitting a Logan curve through the weekly mycelial growth rates at different temperatures, accurate estimates were obtained for two cardinal temperatures of the temperature growth curve for $R$. carotae isolate 840 , i.e. an optimum of $19^{\circ} \mathrm{C}$ and a maximum of $29^{\circ} \mathrm{C}$. With its ability to grow at $0-5^{\circ} \mathrm{C}$, its optimum growth temperature $>15^{\circ} \mathrm{C}$ and its upper limit for growth $>20^{\circ} \mathrm{C}, R$. carotae meets the specifications of psychrotrophic (psychrotolerant) microorganisms (Morita, 1975; Singleton \&
Sainsbury, 1987). Despite its cold tolerating nature, the pathogen failed to penetrate wounded root tissues at $0^{\circ} \mathrm{C}$. The rate of development of defence barriers in the periderm tissues was probably faster than the rate of germination and growth of $R$. carotae. The development of brown lesions at $3-20^{\circ} \mathrm{C}$ (Table 10 ), on the other hand, demonstrates that at these temperatures the pathogen could outgrow the host's defence mechanisms. The absence of infections at $30^{\circ} \mathrm{C}$ is certainly connected with the inability of $R$. carotae to grow at this temperature. Because $R$. carotae, as is the case with the black spot pathogens $M$. acerina (Lewis, Davies, \& Garrod, 1981) and T. basicola (Punja, Chittaranjan, \& Gaye, 1992), is able to infect open wounds at temperatures used in curing procedures, it remains to be seen whether pre-storage temperature treatments can prevent wounds, already contaminated at harvest, from becoming infected. Only wounds which are already healed are no longer amenable to infection by $M$. acerina and T. basicola. For that reason the positive effect of pre-storage temperature treatments described by Hoftun (1993) might not be the result of speeding up wound healing, but could just as well be connected with the colonization of the wounded tissue by antagonists amongst the resident microflora of the carrot rhizoplane. Treating wounds with antagonists might even be more effective in controlling root decay by $R$. carotae than temperature treatments supporting wound healing. The availability of the roots on the elevator of 'top-lift'-type carrot harvesters offers possibilities to apply such biological control agents.

The present study demonstrates that $R$. carotae can infect wounds and thrives at the low temperatures occurring during cold storage of carrot roots. There are indications that umbelliferous plants or their remains may be sources of inoculum. However, the life cycle of $R$. carotae is unknown. Wild and cultivated umbelliferous plants and crop remains or soil need to be tested for the presence of the pathogen. With conventional mycological methods the slow growth of $R$. carotae brings about the risk of the pathogen remaining undetected because it is overgrown by other fungi. These disadvantages can be circumvented by the use of molecular detection methods. 
Molecular tools, such as real-time PCR, may also be usable to assess effects of control measures such as curing.

Acknowledgements This study was supported by the Dutch Ministry of Agriculture, Nature and Food Quality LNV programme 342 and by the Dutch Product Board Horticulture.

\section{References}

Agrios, N. G. (1997). Plant Pathology (4th ed.). New York: Academic Press.

Årsvoll, K. (1965). Acrothecium carotae n.sp., a new pathogen on Daucus carotae L. Acta Agriculturae Scandinavica, 15, 101-114.

Årsvoll, K. (1971). Acrothecium carotae. Sporulation, spore germination, and pathogenesis. Acta Agriculturae Scandinavica, 21, 3-10.

Boller, T., \& Keen, N. T. (2000). Resistance genes and the perception and transduction of elicitor signals in hostpathogen interactions. In A. J. Slusarenko, R. S. S. Fraser, \& L. C. Van Loon (Eds.), Mechanisms of resistance to plant diseases (pp. 189-230). Dordrecht, The Netherlands: Kluwer Academic Publishers.

Bostock, R. M., \& Stermer, B. A. (1989). Perspectives on wound healing in resistance to pathogens. Annual Review of Phytopathology, 27, 343-371.

Braun, U. (1994). Miscellaneous notes on phytopathogenic Hyphomycetes. Mycotaxon, 51, 37-68.

De Hoog, G. S., \& Van Oorschot, C. A. N. (1985). Taxonomy of the Dactylaria complex, VI. Key to the genera and check-list of epithets. Studies in Mycology, 26, 97-122.

Den Belder, E., Elderson, J., Van den Brink, W. J., \& Schelling, G. (2002). Effect of woodlots on thrips density in leek fields: A landscape analysis. Agriculture, Ecosystems and Environment, 91, 139-145.

Ellis, M. B. (1971). Dematiaceous hyphomycetes. Oxon, United Kingdom: CABI Publishing.

Ewaldz, T. (1997). Kemisk bekämping mot lagringsrötor i morötter. Resultat från försök i södra och mellersta Sverige 1991-1993 [Fungicide treatments against storage rots of carrots. Results from field trials in southern Sweden 1991-1993]. Växtskyddsnotiser, 61(1), 8-13.

Hobolth, L. A. (1983). Ny sygdom i gulerødder gulerodsortplet. Gartner Tidende, 83, 205.

Hoftun, H. (1993). Nedkjøling av gulrot. Verknad på lagringsevne og kvalitet [Prestorage of carrots. Effects on storability and quality]. Norsk landbruksforsking, 7, 147-155.

Houba, V. J. G., Van der Lee, J. J., \& Novozamsky, I. (1997). Soil and plant analysis, part 5B: Other procedures. The Netherlands: Wageningen University.

Jönsson, B. (2004). Grönsaker - Har vi fått in nya skadegörare? Potatis \& Grönsaker, 22(4), 6-8.
Krupinsky, J. M., Bailey, K. L., McMullen, M. P., Gossen, B. D., \& Turkington, T. K. (2002). Managing plant disease risk in diversified cropping systems. Agronomy Journal, 94, 198-209.

Lewis, B. G., Davies, W. P., \& Garrod, B. (1981). Woundhealing in carrot roots in relation to infection by Mycocentrospora acerina. Annals of Applied Biology, 99, 35-42.

Logan, J. A., Wollkind, D. J., Hoyt, S. C., \& Tanigoshi, L. K. (1976). An analytic model for description of temperature dependent rate phenomena in arthropods [Tetranychus mcdanieli, apple pests]. Environmental Entomology, 5, 1133-1140.

Meier, R. (1998). De schrik van elke peenteler: Zwarte vlekken. PAV-Bulletin Vollegrondsgroenteteelt, November 1998, 17-19.

Moerschbacher, B., \& Mendgen, K. (2000). Structural aspects of defence. In A. J. Slusarenko, R. S. S. Fraser, \& L. C. Van Loon (Eds.), Mechanisms of resistance to plant diseases (pp. 231-278). Dordrecht, The Netherlands: Kluwer Academic Publishers.

Morita, R. Y. (1975). Psychrophilic bacteria. Bacteriological Reviews, 39, 144-167.

Payne, R. W., Harding, S. A., Lane, P. W., Murray, D. A., Soutar, D. M., Baird, D. B., Welham, S. J., Cherry, M., Kane, A. F., Gilmour, A. R., Thompson, R., Todd, A. D., Webster, R., \& Tunnicliffe Wilson, G. (2002) The guide to GenStat release 6, part 2: Statistics. Hemel Hempstead: VSN International.

Pettersson, M.-L. (1992). Växtskyddsåret 1991- Trädgård [Horticultural pests and diseases in 1991]. Växtskyddsnotiser, 56(1), 2-6.

Punja, Z. K., Chittaranjan, S., \& Gaye, M. M. (1992). Development of black root rot caused by Chalara elegans on fresh market carrots. Canadian Journal of Plant Pathology, 14, 299-309.

Shoemaker, R. A., Hambleton, S., Lacroix, M., Tesolin, M., \& Coulombe, J. (2002). Fungi Canadenses No. 344. Canadian Journal of Plant Pathology, 24, 359362.

Singleton, P., \& Sainsbury, D. (1987). Dictionary of microbiology and molecular biology (2nd ed.) New York: Wiley-Interscience publications.

Snowdon, A. L. (1991). A colour atlas of post-harvest diseases and disorders of fruits and vegetables, Vol. 2: Vegetables. England: Wolfe Scientific Ltd.

Tabachnik, M., DeVay, J. E., Garber, R. H., \& Wakeman, R. J. (1979). Influence of soil inoculum concentrations on host range and disease reactions caused by isolates of Thielaviopsis basicola and soil assay methods. Phytopathology, 69, 974-977.

Temminghoff, E. J. M., Houba, V. J. G., Van Vark, W., \& Gaikhorst, G. A. (2000). Soil and plant analysis, part 3: Plant analysis procedures. The Netherlands: Wageningen University.

Tucker, W. G. (1974). The effect of mechanical harvesting on carrot quality and storage performance. Acta Horticulturae, 38, 359-372. 